\title{
Pectoral Nerves Blocks for Post-Operative Analgesia after Breast Cancer Surgery
}

\author{
OMAR F. SHATOURY YOUNIS, M.Sc.; MOSTAFA K. FOUAD, M.D.; JEHAN A. GOMAA, M.D. and \\ RAHAM H. MOSTAFA, M.D.
}

The Department of Anesthesia, ICU and Pain Management at ASU, Faculty of Medicine, Ain Shams University

\begin{abstract}
Background: Breast cancer is the world's most common cancer among women, surgey is one of the main treatments for this disease. Several ways to prevent post mastectomy pain were used, one of them is the pectoral nerves blocks ( PECs Blocks).
\end{abstract}

Aim of Study: Study aimed to evaluate the efficacy of ultrasound guided Pectoral neves blocks for post-operative analgesia after modified radical mastectomy surgery.

Patients and Methods: The study was carried out on fourty adult female patients, who were scheduled for elective unilateral modified radical mastectomy, they were randomly assigned to two groups, Pectoral nerves block (Pecs) group, included twenty patients who received preoperative Pecs blocks (combination of Pecs I and Pecs II) followed by general anesthesia, and control group which included twenty patients who received general anesthesia only.

Results: It was found that VAS score was statistically significant higher in control group than Pecs group. There was a significant difference concerning the total dose of nalbuphine consumption in 24 hours post-operative between both groups which is lower in Pecs group than in control group. There was a higher satisfaction scores were obtained in Pecs group than in control group with no detected complications other than PONV.

Conclusion: The Pecs blocks produce excellent analgesia when combined with general anesthesia for modified radical mastectomy surgery. They are simple, easy-to-learn techniques, having easily identifiable landmarks based on good anatomical and ultrasound knowledge, making them an excellent alternative to the conventional thoracic paravertebral and neuroaxial blocks for breast surgeries. Also ultrasound guided Pecs blocks significantly reduces VAS.

Key Words: Pectoral Nerves Blocks - Post-operative Analgesia-Breast Cancer Surgery.

Correspondence to: Dr. Omar F. Shatoury Younis, The Department of Anesthesia, ICU and Pain Management at ASU, Faculty of Medicine, Ain Shams University

\section{Introduction}

BREAST cancer is a major health burden worldwide. According to the latest report of The International Agency for Research on Cancer (GLOBOCAN 2012), breast cancer is the world's most common cancer among women, and the most likely cause of death worldwide. The age-specific incidence rates in Egypt show a progressive increase after the age of 30 years, to reach a sharp peak at the age group of 60-64 years [1]. The main treatments for breast cancer are surgery, radiotherapy, chemotherapy, hormonal therapy and biological therapy. The type and the combination of treatments depend on the type of the cancer and its stage. Surgery is usually the first choice of treatment for breast cancer [2]. After breast surgeries acute postoperative pain may occurs significantly and it may progress to chronic pain [3].

Unfortunately, even after adequate treatment, some patients experience severe pain either due to disease progression or due to treatment related side effects. The persistent pain causes a negative physical and psychosocial impact on patients' lives. Usually adequate analgesia is achieved by adopting the WHO's three steps analgesic ladder. As the disease progresses, the pain experienced by the patient also increases. This necessates the administration of opioids and adjuvant analgesics to the breast cancer patients experiencing severe pain. However, opioid use is associated with intolerable side effects like constipation, nausea, vomiting, fear of dependence, and tolerance. Concomitant medications are required to combat these unacceptable side effects. Adjuvant analgesics need to be added to provide adequate and satisfactory analgesia. These factors worsen the psychological state of patients and deteriorate their quality of life. Hence, there is a need to develop therapeutic 
modalities to provide adequate analgesia with minimum side effects [4]. Thoracic epidural and paravertebral blocks became the gold standard techniques to povide analgesia post breast surgery, but not every anesthesiologist is comfortable performing these procedures $[5,6]$. As an alternative for these techniques, a novel series of blocks (Pecs I and Pecs II). The Pecs block type I is a recently described, easy and reliable superficial block that targets the lateral and medial pectoral nerves at an interfascial plane between the pectoralis major ( $\mathrm{PMm}$ ) and minor (Pmm) muscles. A second version of the Pecs block type I, we call it "modified Pecs's block" or Pecs block type II. This novel approach aims to block the axilla that is vital for axillary clearances and the intercostal nerves, necessary for wide excisions, tumor rescetion, sentinel node excision and several types of mastectomies [7]. This novel approach aims to block at least the pectoral nerves, the intercostobrachial nerve, the intercostal nerves III-IV-V-VI and the long thoracic nerve. These nerves need to be blocked to provide complete analgesia during breast surgery [8].

\section{Aim of the work:}

Evaluation of the efficacy of ultrasound guided Pectoral neves block for post-operative analgesia in modified radical mastectomy surgery.

\section{Patients and Methods}

\section{Patients:}

After the approval of the Ethical Committee of Sohag Cancer Institute, the present study was carried out on adult female patients admitted to Sohag Cancer Institute during 2019. Written informed consent was obtained from every patient in this study. All patients were included in the study were American Society of Anesthesiologists ( ASA) physical status I or II, and scheduled for unilateral modified radical mastectomy. All patients included in this study were randomly assigned to two groups:

1- Pectoral nerves block (Pecs) group: Included 20 patients who received preoperative Pecs blocks (combination of Pecs I and Pecs II) followed by general anesthesia.

2- Control group: Included 20 patients who received general anesthesia only.

\section{Inclusion criteria:}

1- American Society of Anesthesiologists (ASA) physical status I or II.

2- Unilateral elective modified radical mastectomy.
3- Age from 20yrs to 60yrs.

Exclusion criteria:

1 - Patient refusal.

2- Allergy to local anesthetics or any of the included medications.

3- Contraindications to regional anesthesia including coagulopathy and local infection.

4- History of treatment of chronic pain condition or psychiatric disorder.

5- Bilateral breast surgeries.

6- Morbid obesity (BMI $\left.>40 \mathrm{~kg} / \mathrm{m}^{2}\right)$.

\section{Methods:}

\section{A-Pre-operative evaluation:}

All the patients were evaluated the day before surgery through:

1- Demographic data (age, BMI, ASA physical status).

2- Proper history taking included medical history for chronic diseases, medications and previous surgeries.

3- Clinical examination included, general condition, cardiovascular system, respiratory system and abdomen.

4- Routine laboratory investigations included complete blood picture, coagulation profile, renal function and liver function.

\section{B-Pre-anesthetic management:}

All patients were premedicated with $5 \mathrm{mg}$ of oral diazepam on the night of surgery. In the preoperative holding area, patients were attached to standard ASA monitors, and Intravenous (IV) access was inserted. Premedication with IV 1 to $2 \mathrm{mg}$ of midazolam and $10 \mathrm{mg}$ of metoclopramide were administered to all patients. The patients in the control group were then transferred immediately to the operating room, whereas the patients in the Pecs group received an ultrasound-guided Pecs block and a 15 minute observation time prior to their transfer to the operating room.

\section{Pecs block group:}

Patients in the Pecs blocks group received a combination of Pecs I and Pecs II blocks. The patient laid in supine position and a high frequency linear probe $(10 \mathrm{MHz})$ was covered with sterile sheath and used for the scanning after disinfection of the skin. For Pecs I, the probe was positioned in the parasagittal plane below the lateral half of the clavicle. The pectoral branch of the thoraco- 
acromial artery was identified between the 2 pectoralis muscles using color Doppler.

\section{C-Anesthesia:}

Standard general anesthesia was induced in both groups using intravenous fentanyl $(1 \mathrm{ug} / \mathrm{kg})$, propofol $(2 \mathrm{mg} / \mathrm{kg})$ and cisatracurium $(0.15 \mathrm{mg} / \mathrm{kg})$ to facilitate endotracheal intubation. Anesthesia was maintained with isoflurane $(1 \%-1.5 \%)$ with oxygen-air mixture. Ventilation maintained at a tidal volume of $6-8 \mathrm{ml} / \mathrm{kg}$ and a rate to adjust the end-tidal carbon dioxide at $(30-35 \mathrm{mmHg})$ used the ventilator, incremental doses of cisatracurium 0 . $03 \mathrm{mg} / \mathrm{kg}$ were given till the end of surgery. Incremental doses of fentanyl $(25 \mathrm{~g})$ was given when the heart rate and/or mean arterial blood pressure were more than $20 \%$ from the base line.

\section{D-Post-operative Management: (Post anesthetic care unit, PACU):}

The consciousness level, vital signs as heart rate (beats/min) and mean arterial blood pressure ( $\mathrm{mmHg}$ ) and respiratory rate were observed. All patients received ketorolac 30mg every 8 hours. It started immediately post-operative in the post anesthetic care unit.

\section{Statistical analysis:}

Data entry, processing and statistical analysis was carried out using Statistical package for social sciences (IBM-SPSS), version 24 (May 2016); IBM-Chicago, USA. $p$-value: Level of significance: $p$ $>0.05$ : Non-Significant (NS), $p<0.05$ : Significant ( $\mathrm{S}), p<0.01$ : Highly Significant (HS).

\section{Results}

Table (1): Demographic data and duration of surgery.

\begin{tabular}{|c|c|c|c|}
\hline & $\begin{array}{l}\text { Control group } \\
\text { No. }=20\end{array}$ & $\begin{array}{l}\text { Pecs group } \\
\text { No. }=20\end{array}$ & $\underset{\text { value }}{p \mathrm{~S} 1 \mathrm{~g} .}$ \\
\hline \multicolumn{4}{|l|}{ Age: } \\
\hline Mean \pm SD & $44.90 \pm 8.45$ & $48.50 \pm 8.37$ & $0.092 \mathrm{NS}$ \\
\hline Range & $30-59$ & $27-60$ & \\
\hline \multicolumn{4}{|l|}{ BMI: } \\
\hline Mean \pm SD & $29.35 \pm 3.57$ & $29.95 \pm 2.32$ & $0.266 \mathrm{NS}$ \\
\hline Range & $23-36$ & $27-34$ & \\
\hline $\begin{array}{l}\text { Duration of surgery/min: } \\
\text { Mean } \pm \mathrm{SD} \\
\text { Range }\end{array}$ & $\begin{array}{l}105.25 \pm 10 . \\
27 \\
90-120\end{array}$ & $\begin{array}{l}102.75 \pm 12.71 \\
80-120\end{array}$ & $0.249 \mathrm{NS}$ \\
\hline \multicolumn{4}{|l|}{ ASA classification: } \\
\hline Median & 1.5 & 1 & $0.379 \mathrm{NS}$ \\
\hline Range & $1-2$ & $1-2$ & \\
\hline
\end{tabular}

Fourty patients ASA I and II were enrolled in the study. They were divided into two groups each contains twenty patients. The two groups completed the study. There were no statistically significant difference between the two groups as regards age, BMI, ASA physical status or duraion of surgery.

\section{2- Peri-operative analgesic consumption:}

A- Intraoperative fentanyl consumption: There was a significant difference between the two groups in intraoperative fentanyl consumption. The total number of patients needed intra operative fentanyl dose in the control group was (18) and in the Pecs group was (9), with $p$-value 0.001 which is significant. The total amount of fentanyl dose used was higher in control group than Pecs group, with $p$ value 0.001 which is significant.

Table (2): Total amount of Fentanyl dose used (mic.).

\begin{tabular}{llll}
\hline $\begin{array}{l}\text { Total amount of Fentanyl } \\
\text { dose used (microgram) }\end{array}$ & $\begin{array}{c}\text { Control group } \\
\text { No.=20 }\end{array}$ & $\begin{array}{c}\text { Pecs group } \\
\text { No.=20 }\end{array}$ & $\begin{array}{c}p- \\
\text { value }\end{array}$ \\
\hline Mean \pm SD & $66.66 \pm 38.99$ & $31 \pm 25$ & $0.001 \mathrm{~S}$ \\
Range & $50-200$ & $25-100$ & \\
\hline
\end{tabular}

$B$ - Post-operative nalbuphine consumption: There was a significant difference between the two groups in post-operative nalbuphine consumption. The total number of patients needed post-operative nalbuphine dose in the control group was (16) while in the Pecs group was (7), with $p$-value ( 0.001 ) which is significant.

Time of first dose of nalbuphine needed postoperative was earlier in control group than that at Pecs group with $p$-value (0.029). The total amount of nalbuphine dose used during $24 \mathrm{hrs}$ was higher in control group than Pecs goup, with $p$-value ( 0.001) which is significant.

Table (3): Total amount of Nalbuphine dose used (mg) and time of first dose of nalbuphine needed postoperative/mins.

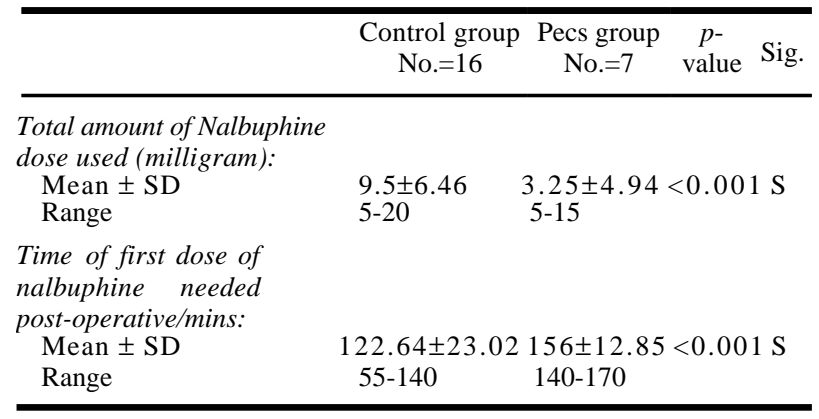

Table (4): Comparison between the two studied groups as regarding heart rate intra-operative.

\begin{tabular}{|c|c|c|c|c|}
\hline \multirow[t]{2}{*}{ HR } & \multirow{2}{*}{$\begin{array}{l}\text { Control group } \\
\text { Mean } \pm \text { SD }\end{array}$} & \multirow{2}{*}{$\begin{array}{c}\text { Pecs group } \\
\text { Mean } \pm \text { SD }\end{array}$} & \multicolumn{2}{|c|}{$\begin{array}{c}\text { Independent } \\
t \text {-test }\end{array}$} \\
\hline & & & $p$-value & Sig. \\
\hline Intra-op. pre induction & $84.75 \pm 21.40$ & & 0.966 & NS \\
\hline Intra-op. Post intubation & $78.90 \pm 10.64$ & $76.88 \pm 961$ & 0.516 & NS \\
\hline after $10 \mathrm{mins}$ & $82.35 \pm 9.26$ & & 0.089 & NS \\
\hline After $20 \mathrm{mins}$ & $82.85 \pm 10.63$ & $89.55+9.69$ & 0.479 & NS \\
\hline After 30mins & $87.95 \pm 6.64$ & $78.00 \pm 10$ & 0.003 & $\mathrm{~S}$ \\
\hline After $60 \mathrm{mins}$ & $85.45 \pm 7.16$ & $80.00 \pm 10$. & 0.014 & $\mathrm{~S}$ \\
\hline After 90mins & $85.58 \pm 8.14$ & $\begin{array}{l}0 \% .94 I 11 . \\
11\end{array}$ & 0.270 & NS \\
\hline After $120 \mathrm{mins}$ & $94.00 \pm 7.44$ & $84.17 \pm 9.17$ & 0.039 & $\mathrm{~S}$ \\
\hline
\end{tabular}


There was a significance difference between the two group in heart rate changes post-operatively since arrival to PACU till $16 \mathrm{hrs}$ post-operatively. At the 24th hrs post-operative there was no significant difference between the groups as regarding HR.

Table (5): Comparison between the two studied groups as regarding heart rate post-operative.

\begin{tabular}{|c|c|c|c|c|}
\hline \multirow[t]{2}{*}{ HR } & \multirow{2}{*}{$\begin{array}{l}\text { Control group } \\
\text { Mean } \pm \text { SD }\end{array}$} & \multirow{2}{*}{$\begin{array}{c}\text { Pecs group } \\
\text { Mean } \pm S D\end{array}$} & \multicolumn{2}{|c|}{$\begin{array}{c}\text { Independent } \\
t \text {-test }\end{array}$} \\
\hline & & & $p$-value & Sig. \\
\hline $\begin{array}{l}\text { - Post-op. at arriaval } \\
\text { to PACU }\end{array}$ & $85.20 \pm 7.00$ & $79.80 \pm 8.68$ & 0.037 & $S$ \\
\hline - After $2 \mathrm{hrs}$ & $87.85 \pm 7.43$ & $81.75 \pm 8.09$ & 0.017 & $\mathrm{~S}$ \\
\hline - After $6 \mathrm{hrs}$ & $91.1 \pm 6.62$ & $84.95 \pm 10.63$ & 0.034 & $\mathrm{~S}$ \\
\hline - After $10 \mathrm{hrs}$ & $86.35 \pm 9.43$ & $83.30 \pm 8.81$ & 0.297 & NS \\
\hline - After $16 \mathrm{hr}$ & $89.45 \pm 6.46$ & $82.85 \pm 10.39$ & 0.021 & $\mathrm{~S}$ \\
\hline - After $24 \mathrm{hr}$ & $81.20 \pm 7.14$ & $79.05 \pm 12.01$ & 0.495 & NS \\
\hline
\end{tabular}

Table (6): Comparison between the two studied groups as regarding mean $\mathrm{ABP}$ post-operative.

\begin{tabular}{|c|c|c|c|c|}
\hline \multirow{2}{*}{ Mean ABP } & \multirow{2}{*}{$\begin{array}{l}\text { Control group } \\
\text { Mean } \pm S D\end{array}$} & \multirow{2}{*}{$\begin{array}{l}\text { Pecs group } \\
\text { Mean } \pm \text { SD }\end{array}$} & \multicolumn{2}{|c|}{$\begin{array}{c}\text { Independent } \\
t \text {-test }\end{array}$} \\
\hline & & & $p$-value & Sig. \\
\hline $\begin{array}{l}\text { - Post-op. at arriaval } \\
\text { to PACU }\end{array}$ & $95.30 \pm 6.67$ & $90.10 \pm 6.19$ & 0.014 & $S$ \\
\hline - After $2 \mathrm{hrs}$ & $95.55 \pm 7.36$ & $91.35 \pm 5.51$ & 0.048 & S \\
\hline - After $6 \mathrm{hrs}$ & $97.55 \pm 5.02$ & $92.20 \pm 8.31$ & 0.018 & $\mathrm{~S}$ \\
\hline - After $10 \mathrm{hrs}$ & $96.20 \pm 6.78$ & $94.10 \pm 6.26$ & 0.315 & NS \\
\hline - After $16 \mathrm{hr}$ & $97.05 \pm 6.50$ & $92.55 \pm 6.07$ & 0.029 & $\mathrm{~S}$ \\
\hline - After $24 \mathrm{hr}$ & $93.75 \pm 7.57$ & $92.65 \pm 8.62$ & 0.670 & NS \\
\hline
\end{tabular}

There was a significance difference between the two group in MABP changes post-operatively since arrival to PACU till $16 \mathrm{hrs}$ post-operatively. It was lower in Pecs group than in control group. At the 24th hrs post-operative there was no significant difference between the groups as regarding MABP.

Table (7): Comparison between the two studied groups as regarding patient satisfaction.

\begin{tabular}{lllll}
\hline $\begin{array}{l}\text { Patient satisfaction } \\
\text { after 24hr }\end{array}$ & $\begin{array}{c}\text { Control group } \\
\text { No.=20 }\end{array}$ & $\begin{array}{c}\text { Pecs group } \\
\text { No.=20 }\end{array}$ & $\begin{array}{c}p \text { - } \\
\text { value }\end{array}$ & Sig. \\
\hline $\begin{array}{l}\text { Mean } \pm \text { SD } \\
\text { Range }\end{array}$ & $3.60 \pm 1.19$ & $\begin{array}{l}4.45 \pm 0.76 \\
3-5\end{array}$ & 0.010 & S \\
\hline
\end{tabular}

There was a significant difference between the two group as regarding patient satisfaction, that patients at Pecs group were more satisfied than those in control group.

\section{Discussion}

The Pecs block is a combination of motor and sensory nerve blocks, one advantage of Pecs block, requiring emphasis, is that it is not associated with sympathetic block as are the TPVB and epidural blocks, on the other hand, intravascular injection into the pectoral branch of the acromiothoracic artery is another possibility that could be considered, complications should be easily avoidedwith proper ultrasound training and searching for the right pattern of spread of the local anesthetic [7].

The aim of the present study was to evaluate the efficacy of ultrasound guided pectoral nerves blocks for post-operative analgesia in modified radical mastectomy surgery.

This study was conducted on 2 groups, ASA ( I, II) physical classification, female patients undergoing unilateral modified radical mastectomy ( 20 patients in each group). Patients of group 1 received general anethesia alone and patients of group 2 received general anethesia with Pecs block. Measurements were age, BMI, duration of surgery, vital signs, perioprative opioid consumption, pain intensity usnig VAS scale, any reported complications, and patient satisfaction verbal score.

In our study, regarding the demographic data ( age and BMI), ASA physical status and duration of surgery there was no significant difference between both groups. Regarding intraoperative and post-operative heart rate and mean $\mathrm{ABP}$ changes there was a highly significant difference between the two groups with higher HR and MABP in the control group starting from the 10th minute after inubation, till the 16th hour post-operatively ( $p$ value $<0.05$ ) (it was higher in control group than in Pecs group, without hypotension or bradycardia in Pecs group while in control it was higher may be due to pain sensation as it was decreased with administration of fentanyl). Also there was ahigher intra operative fentanyl consumption in the control group compared with the Pecs group with a mean $66.66 \pm 38.99$ mic.fentanyl in control group vs. 31 \pm 25 mic.fentanyl in Pecs group ( $p$-value $=0.001$ ) and the total number of patients needed fentanyl in the control group was 18 vs. 9 in the Pecs group ( $p$-value $=0.001)$. Additionally there was a higher post-operative nalbuphine consumption in the control group compared with the Pecs group with a mean $9.5 \pm 6.46 \mathrm{mg}$ nalbuphine in control group vs. $3.25 \pm 4.94 \mathrm{mg}$ nalbuphine in Pecs group ( $p$ value $=0.001$ ) and the total number of patients needed nalbuphinein the control group was 16 vs. 7 in the Pecs group ( $p$-value $=0.001$ ), the time of the first request of anlagesia postoperaively was earlier in the control group (after 55mins) than in Pecs group (after 140mins) with $p$ value $<0.001$. Lower pain scores were observed in natients un- 
dergoing MRM with pre emptive Pecs block than in the controls using VAS scale. Finally, lower opioid-related side effects with lower PONV score in the Pecs group were reported with high satisfaction score in Pecs group than in control group.

In agreement with the our study, Bashandy et al., stated that intra-operative fentanyl requirements were found to be lower in the Pecs group than in the control group (number of patients in each group was 60 and total dose of fentanyl in each group was $115 \pm 28.56 \mathrm{~g}$ and $252.5 \pm 44.352 \mathrm{~g}$, respectively). Also, statistically significant lower visual analog scale pain scores, postoperative morphine consumption were observed in patients who received Pecs II block with ultrasound pre-operatively than in the control group patients who received general anesthesia alone for breast cancer surgery [3]. They conducted their study on 120 female patients, age from $20 \mathrm{yrs}$ to $60 \mathrm{yrs}$, ASA 1 and 2 physical status, who underwent elective modified radical mastectomy surgery. They differ from our study that they used bupivacaine alone without adrenaline, also they used morphine as a postoperative analgesic rescuer drug and they used patient controlled analgesia PCA system.

Also in agreement with our study, Thomas et al., stated that Pecs blocks delivered under vision reduced analgesic requirement and pain scores significantly [9]. They conducted their study on 60 female patients, 30 cases in each group: Group A ( Pecs block) and group B (saline infiltration group or placebo group), age from $18 \mathrm{yrs}$ to $70 \mathrm{yrs}$, ASA 1 and 2 physical status, who underwent elective modified radical mastectomy surgery. The mean duration of analgesia was significantly longer in Group A (Pecs block) than in Group B (placebo group); 354 minutes versus 27 minutes. Group A did not require any fentanyl post-operatively but Group B required a mean fentanyl dose of $34.67 \pm$ $13.58 \mathrm{~g}$ post-operatively. The mean dose of paracetamol required was significantly less in Group A than in Group B over $24 \mathrm{~h}$ (2.7gm versus $3.5 \mathrm{gm})$. Significantly more patients had mild pain and fewer patients had moderate pain in Group A compared to Group B both at rest and on movement, at all measured time points. None of the patients developed any adverse events such as local anesthetic toxicity, hemodynamic instability, respiratory depression, paresthesia, pneumothorax, hematoma, re-explorations, or nausea and vomiting Thomas's study differs from our study in that: It is placebocontrolled, three-blinded study, the block was done under vision at the end of surgery before skin closure, also they used ropivacaine $0.2 \%$ as alocal anecthetic acent wxith doce $3 \cap \mathrm{ml}$ for ornun $\Delta(7 \mathrm{nml}$ for Pecs 1 and $10 \mathrm{ml}$ for Pecs 2), and 30ml saline $0.9 \%$ for group B. Also they used fentanyl as a post-operative analgesic rescuer drug. Finally, longer duration of timing to $1{ }^{\text {st }}$ request of analgesia post-operatively was noticed in Pec's group, and this is due to the fact that their block was given at the end of resection and after wash. Consequently, the local anesthetic solution was more likely to be contained in the tissue plane in which it was deposited than a pre-operatively deposited solution that might leak out intraoperatively during tissue dissection.

Finally, in agreement with the our study, Sinha et al., stated that Pecs 2 block is a potentialanalgesic technique alternative to Erector Spinae Block (ESB) after breast surgery. It provides better pain scores with lesser opioid requirement in comparison with ESP [10]. They conducted their study on 64 female patients 32 case in each group (pecs 2 group and ESP group), age from 20yrs to 60yrs, ASA 1 and 2 physical status, who underwent elective modified radical mastectomy surgery. They differ from our study that they compare pecs 2 block with another block not a control group, also they used ropivacaine $0.2 \%$ as alocal anesthetic agent with doses, $15 \mathrm{ml}$ for Pecs 2 block and $20 \mathrm{ml}$ for ESP block, also they used morphine as a post-operative analgesic rescuer drug and PCA system.

On contrary to the present study, Razek et al., stated that Serratus Intercostal Plane Block (SIPB) provided superior post-operative analgesia compared with Pecsblock in patients undergoing nonreconstructive breast surgeries [11]. They conducted their study on 60 female patients (30 cases in Pecs group and 30 cases in SIPB group), age from $20 \mathrm{yrs}$ to $60 \mathrm{yrs}$, ASA 1 and 2 physical status, who undergoing nonreconstructive breast surgeries. They used levobupivacaine $0.25 \%$ with adrenaline 1 : 200000 , 40ml for Pecs block, $10 \mathrm{ml}$ for Pecs 1 and $30 \mathrm{ml}$ for Pecs 2 , and $40 \mathrm{ml}$ for SIPB, they used fentanyl as a post-operative analgesic drug. They founded higher VAS scale in Pecs group than SIPB group, and the time of the first request of fentanyl post-operative was earlier in Pecs group than SIPB group.

Disconcordant to our study, Bakshi et al., have reported difficulty during surgery due to fluid filled spaces after PECS block. We didnot encounter this problem in any of our patients. This could be explained due to the time gap between the block and the surgery (specially that we performed it pre-operatively) which could have led to the absorption of local anesthetic [12]. 
Finally, on contrary to the present study, Ueshima et al., showed that eight hematoma cases among 498 cases of Pecs block have been reported. The hematoma was around the injection site in the eight cases. Five of these patients were receiving anticoagulants and antiplatelet drugs [13]. The differ from our study that there was no hematoma occurred in Pecs group, may be due to selection of patient with no coagulopathy or small sample size. There was no complication other than PONV recorded in our study in both groups.

One of the limitations to our study is that the psychological impact of losing a feminine organ in a female patient makes here complaint about pain unreliable to some extent that some patients gave an exaggerated scores to pain score.

As a conclusion, the Pecs blocks produce excellent analgesia when combined with general anesthesia for modified radical mastectomy surgery. They are simple, easy-to-learn techniques, having easily identifiable landmarks based on good anatomical and ultrasound knowledge, making them an excellent alternative to the conventional thoracic paravertebral and neuroaxial blocks for breast surgeries. Also ultrasound guided Pecs blocks significantly reduces VAS.

\section{Conclusion:}

The Pecs blocks produce excellent analgesia when combined with general anesthesia for modified radical mastectomy surgery. They are simple, easy-to-learn techniques, having easily identifiable landmarks based on good anatomical and ultrasound knowledge, making them an excellent alternative to the conventional thoracic paravertebral and neuroaxial blocks for breast surgeries. Also ultrasound guided Pecs blocks significantly reduces VAS.

\section{References}

1- AZIM, HAMDY A., and AMAL S. IBRAHIM: Breast cancer in Egypt, China and Chinese: Statistics and beyond.J. Thorac. Dis., 6 (7): 864-6, 2014.
2- MAUGHAN K.L., LUTTERBIE M.A. and HAM P.S. Treatment of breast cancer. Am. Fam. Physician, 81 (11): 1339-46, 2010.

3- BASHANDY G.M.N. and ABBAS D.N.: Pectoral nerves I and II blocks in multimodal analgesia for breast cancer surgery: A randomized clinical trial. Reg. Anesth. Pain Med., 40 (1): 68-74, 2015.

4- HANDY C.R., KRUDY C. and BOULIS N.: Gene therapy: A potential approach for cancer pain. Res. Treat., 2011: 987597, 2011.

5- SCHNABEL A., REICHL S.U., KRANKE P., POGATZKI-ZAHN E.M. and ZAHN P.K.: Efficacy and safety of paravertebral blocks in breast surgery: A meta-analysis of randomized controlled trials. Br. J. Anaesth, 105: 84252,2010 .

6- NORUM H.M. and BREIVIK H.: Thoracic paravertebral blockade and thoracic epi- dural analgesia: Two extremes of a continuum. Anesth. Analg., 112: 990, 2011.

7- BLANCO R., FAJARDO M. and PARRAS MALDONADO T.: Ultrasound description of Pecs II (modified Pecs I): A novel approach to breast surgery. Rev. Esp. Anestesiol. Reanim., 59: 470-5, 2012.

8- KLEIN S.M., BERGH A., STEELE S.M., GEORGIADE G. S. and GREENGRASS R.A.: Thoracic paravertebral block for breast surgery. Anesth. Analg., 90: 1402-5, 2000.

9- THOMAS M., PHILIP F.A., MATHEW A.P. and KRISHNA K.J.: Intraoperative pectoral nerve block $(\mathrm{Pec})$ for breast cancer surgery: A randomized controlled trial. Journal of anaesthesiology, clinical pharmacology, Jul., 34 (3): 318, 2018.

10- SINHA C., KUMAR A., KUMAR A., PRASAD C., SINGH P.K. and PRIYA D.: Pectoral nerve versus erector spinae block for breast surgeries: A randomised controlled trial. Indian Journal of Anaesthesia, Aug., 63 (8): 617, 2019.

11- BAKSHI S., KARAN N. and PARMAR V.: Pectoralis block for breast surgery: A surgical concern? Indian Journal of Anesthesia, Oct. 1, 61 (10), 2017.

12- UESHIMA H. and OTAKE H.: Ultrasound-guided pectoral nerves (PECS) block. Complications observed in 498 nnncanutiva macas I Clin Anacth 10.16 0017 


\section{التخدير الموضعى للآعصاب الصدرية لتسكين الآلم ما بعل جراحة سرطان الثلدى الهري}

يساعد علاج الآلم الفعال لمرضى العمليات الجراحية على الصد من حدق المضاعفات المصاحبة لهذه العمليات الجراحية، وهذا يؤدى المها

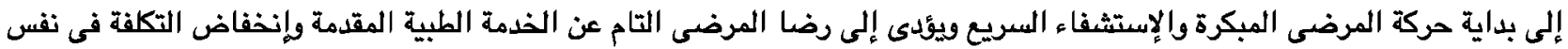

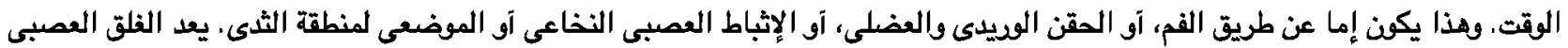

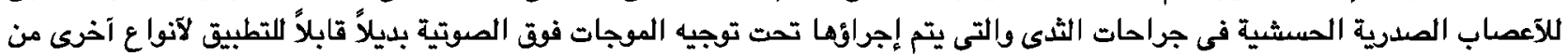
التخدير الموضعى التى لها تآثير جانبي متزايد.

الهدف من هذه الدراسة: تقييم تسكين الآلم وبعد العمليات الجراحية غير التحفظية للثىى مع إخلاء الإبط بواسطة الموجات فوق الصوتية الإسترشادية لعمل غلق عصبى للآعصاب الصدئ الدرية.

آجريت هذه الدراسة على آربعين من نساء مرضى الثىى البالغين آعمارهن ما بين الثلاثين والستين عاماً من التصنيف الآول والثانى لجمعية

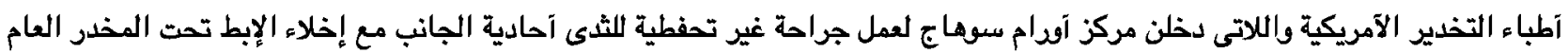

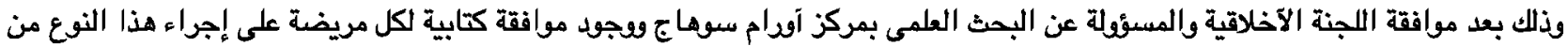

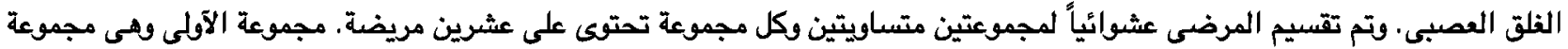
الغلق العصبى للآعصاب الصدرية ومعه تخدير كلى والمجموعة الثانية وهى مجموعة تلقت تخدير كلى فقط.

ومن خلال هذه الدراسة تم ملاحظة إنخفاض نسبة إستهلاك العقاقير المسكتة للالكم فى مجموعة الغلق العصبى عن المجموعة التى لم تتلقى

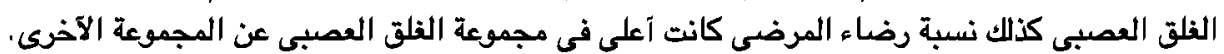

النتيجة العامة: آن الغلق العصبى للآعصاب الصدرية من آنواع التخدير الموضعى الآمنة والفعالة فى تسكين الآلم ما بعد عمليات إستئصال 